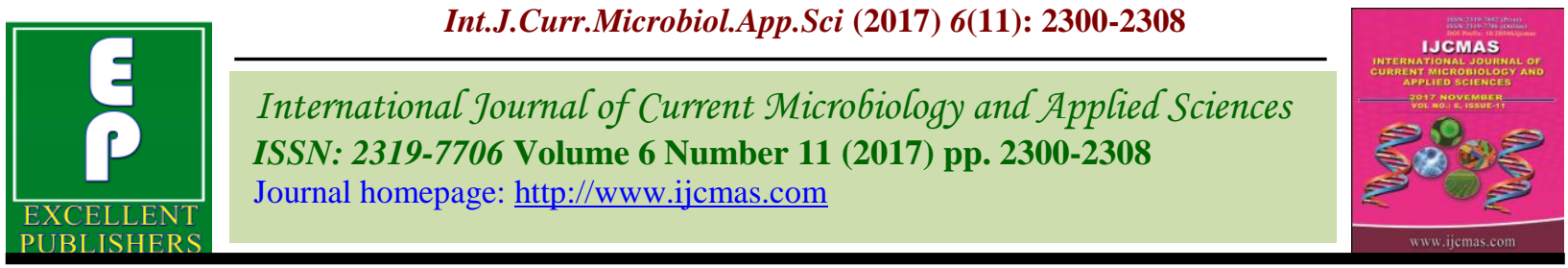

Review Article

https://doi.org/10.20546/ijcmas.2017.611.273

\title{
Certification of Organic Products
}

\section{H.M. Ummyiah*, N. Jabeen, Baseerat Afroza, Faheema Mushtaq, Shahnaz Mufti and Ambreen Nabi}

\author{
Division of Vegetable Science, Sher-e-Kashmir, University of Agricultural Sciences and \\ Technology of Kashmir, Shalimar, Srinagar- 191121, India \\ *Corresponding author
}

\begin{tabular}{|c|c|}
\hline & A B S T R A C T \\
\hline & \multirow{5}{*}{$\begin{array}{l}\text { According to the Food and Agriculture Organization (FAO), sustainable agriculture "is the } \\
\text { successful management of resources for agriculture to satisfy changing human needs while } \\
\text { maintaining or enhancing the quality of environment and conserving natural resources". } \\
\text { Organic agriculture also offers trade opportunities for farmers in the developing and } \\
\text { developed countries. Emerging from } 42,000 \text { ha under certified organic farming during } \\
2003-04 \text {, the organic agriculture has grown almost } 29 \text { fold during the last } 5 \text { years. By } \\
\text { March, } 2010 \text {, India has brought more than } 4.48 \text { million ha area under organic certification } \\
\text { process. However, this market is not very well known to most farmers, especially those } \\
\text { living in the developing countries. In developing countries it is therefore essential for } \\
\text { major key players (e.g. NGOs, farmer organizations, traders, exporters etc.) that promote } \\
\text { organic farming to have up-to-date information on the available opportunities (marke } \\
\text { requirements) and trends of the organic market }\end{array}$} \\
\hline & \\
\hline $\begin{array}{l}\text { Organic products, } \\
\text { Food and Agriculture } \\
\text { Ocganization (FAO). }\end{array}$ & \\
\hline Article Info & \\
\hline $\begin{array}{l}\text { Accepted: } \\
\text { 17 September } 2017 \\
\text { Available Online: } \\
10 \text { November } 2017\end{array}$ & \\
\hline
\end{tabular}

\section{Introduction}

Organic farming is one of the several approaches found to meet the objectives of sustainable agriculture. Many techniques used in organic farming like inter-cropping, mulching and integration of crops and livestock are not alien to various agriculture systems including the traditional agriculture practiced in old countries like India. However, organic farming is based on various laws and certification programmes, which prohibit the use of almost all synthetic inputs, and health of the soil is recognized as the central theme of the method. Adverse effects of modern agricultural practices not only on the farm but also on the health of all living things and thus on the environment have been well documented all over the world. There are several definitions of organic farming and the one given by the US Department of Agriculture (USDA) is considered the most coherent and stringent. It is defined as 'a system that is designed and maintained to produce agricultural products by the use of methods and substances that maintain the integrity of organic agricultural products until they reach the consumer.

Organic agriculture offers trade opportunities for farmers in the developing and developed countries. The absence of sufficient technical and market information and financial support also means that few farmers will risk 
changing their method of production. In developing countries it is therefore essential for major key players (e.g. NGOs, farmer organizations, traders, exporters etc.) that promote organic farming to have up-to-date information on the available opportunities (market requirements) and trends of the organic market. One example is India, a country with a huge number of small farmers who still use traditional methods and do farming with few agricultural inputs. NGOs that promote organic farming and other organizations support farmers in these aspects. Global links have been forged in all continents as organic agriculture has been seen to be an effective rural development option. Although the movement is still regarded with some skepticism (Trewavas, 2001; Kirchmann and Ryan, 2004; Trewavas, 2004), the concept of organic farming has strong marketing appeal, growth forecasts are almost all positive and it has been suggested that the 'movement' is now an 'industry' (Cornish and Stewart, 2002).

\section{Extent of organic production}

Emerging from 42,000 ha under certified organic farming during 2003-04, the organic agriculture has grown almost 29 fold during the last 5 years. By March, 2010, India has brought more than 4.48 million ha area under organic certification process. Out of this, cultivated area accounts for 1.08 million ha, while remaining 3.4 million ha is wild forest harvest collection area.

\section{Organic certification}

To regulate the export of certified organic products, the Director General of Foreign Trade, Government of India has issued a public notice according to which no certified organic products may be exported unless they are certified by an inspection and certifying agency duly accredited by one of the accreditation agencies designated by the Government of India.

\section{Purpose of certification}

It addresses a growing worldwide demand for organic foods.

It is intended to assure quality and prevent fraud.

For organic producers, it identifies suppliers of products approved for use in certified operations.

For consumers it serves as a product assurance.

It is essentially aimed at regulating and facilitating the sale of organic products to consumers.

Individual certification bodies have their own service marks, which can act as branding to consumers.

\section{Indian regulatory mechanism}

For quality assurance the country has internationally acclaimed certification process in place for export, import and domestic market. National Programme on Organic Production (NPOP) defines the regulatory mechanisms and is regulated under two different acts for export and domestic market. NPOP notified under Foreign Trade Development and Regulation Act (FTDR) looks after the export requirement. The NPOP has already been granted equivalence by EU and Sweden. USDA has also accepted the conformity assessment system of NPOP. Due to this the product certified by any Indian Accredited certification agency under NPOP can be exported to Europe, Sweden and USA without re-certification. To look after the import and domestic market NPOP has been 
notified under Agriculture Produce Grading, Marketing and Certification Act (APGMC). Regulatory body of NPOP under FTDR Act is Agricultural and Processed Foods Export Development Authority (APEDA) under Ministry of Commerce and of NPOP under APGMC Act is Agricultural Marketing Advisor (AMA) under Ministry of Agriculture.

20 Accredited certification agencies are looking after the certification (6 under public sector and 14 under private management). Accreditation of certification and inspection agencies is granted by a common National Accreditation Body (NAB).

The National Accreditation Body has designated six Accreditation Agencies including (www.apeda.com);

Agricultural Processed Food Products Export Development Authority (APEDA);

Coffee Board;

Spices Board;

Tea Board;

Coconut Development Board;

Directorate of Cashew and Cocoa Development.

\section{NPOP}

The aims of the National Program for Organic Production include (apeda.gov.in):

Providing the means to evaluate certification programmes for organic agriculture and products as per the approved criteria;

Developing policies for the certification and development of organic products;
Producing the National Standards for Organic Products (NSOP);

Formulating the National Accreditation Policy and Programme (NAPP);

Accrediting certification programmes to be operated by Inspection and Certification agencies.

Facilitating certification of organic products in conformity to the NSOPs;

Developing regulations for the use of the National Organic Certification Mark;

Encouraging the development of organic farming and organic processing.

National standards for organic production (NSOP)

NSOP are grouped under following categories:

\section{Conversion}

The time between the start of organic management and cultivation of crops or animal husbandry is known as the conversion period.

All standard requirements should be met during conversion period. Full conversion period is not required where organic farming practices are already in use.

\section{Crop production}

\section{Choice of crops and varieties}

All seeds and planting materials should be certified organic or chemically untreated.

Use of genetically engineered seeds, pollen, transgenic plants is not allowed. 


\section{Duration of conversion period}

The minimum conversion period for plant products, produced annually is 12 months prior to the start of production cycle.

\section{Fertilization policy}

Biodegradable material of plant or animal origin produced on organic farms should form the basis of fertilization policy.

\section{Pest/disease/weed management including growth regulators}

These should be controlled preferably by preventive cultural techniques. Botanical pesticides prepared at farm from local plants, animals and micro-organisms are allowed.

\section{Soil and water conservation}

Soil and water resources should be handled in a sustainable manner to avoid erosion, salination, excessive and improper use of water and pollution of surface and ground water.

\section{Food processing and handling}

Organic products should be protected from co-mingling with non-organic products.

Certification programme should regulate the means and measures to be allowed or recommended for decontamination, clearing or disinfection of all facilities where organic products are kept, handled, processed or stored.

\section{Packaging}

Material used for packaging should be ecofriendly, biodegradable and should not contaminate the food. Recycling and reusable systems should be used.

\section{Labeling}

When the full standard requirements are met, the product can be sold as 'organic'. On proper certification by certification agency 'India Organic' logo can be used on the product.

APEDA has laid down requirements for mixed products where not all ingredients, including additives are of organic origin may be labelled in the following way:

Where a minimum of $95 \%$ of the ingredients are of certified organic origin, products may be labeled 'certified organic' or similar and should carry the logo of the certification programme.

Where less than $95 \%$ but more than $70 \%$ of the ingredients are of certified organic origin, products may not be called organic.

Where less than $70 \%$ of the ingredients are of certified organic origin, the indication that an ingredient is organic may appear in the ingredient list.

\section{Storage and transport}

Products' integrity should be maintained during storage and transportation of organic products. Organic products should be protected from co-mingling with non-organic products and substances not permitted in organic farming.

\section{Certification procedure in brief}

Application is made to the certification agency in the prescribed format with necessary farm and process details

Screening of application by the cert. agency and if necessary further details/ clarification sought 
List of Accredited Certification Bodies under NPOP

\begin{tabular}{|c|c|c|c|}
\hline $\begin{array}{l}\text { Sr. } \\
\text { No }\end{array}$ & $\begin{array}{l}\text { Name of the Certification } \\
\text { Agency }\end{array}$ & Accreditation & Certification Mark \\
\hline 1 & $\begin{array}{l}\text { Bureau Veritas Certification } \\
\text { IndiaPvt. Ltd., } \\
\text { Mumbai }\end{array}$ & $\begin{array}{l}\text { NPOP } \\
\text { USDA } \\
\text { NOP }\end{array}$ & $\begin{array}{l}\text { Organic Farming } \\
\text { BUREAU VERITAS } \\
\text { Centification }\end{array}$ \\
\hline 2 & $\begin{array}{l}\text { ECOCERT India Pvt. Ltd., } \\
\text { Aurangabad }\end{array}$ & $\begin{array}{l}\text { NPOP } \\
\text { USDA } \\
\text { NOP }\end{array}$ & \\
\hline 3 & $\begin{array}{l}\text { IMO Control Pvt. Ltd. } \\
\text { (Bangalore) }\end{array}$ & $\begin{array}{l}\text { NPOP } \\
\text { USDA } \\
\text { NOP }\end{array}$ & \\
\hline 4 & $\begin{array}{l}\text { Indian Organic Certification } \\
\text { Agency } \\
\text { (INDOCERT) Cochin-Kerela }\end{array}$ & $\begin{array}{l}\text { NPOP } \\
\text { USDA } \\
\text { NOP }\end{array}$ & \\
\hline 5 & $\begin{array}{l}\text { Lacon Quality Certification } \\
\text { Pvt. Ltd., Thiruvalla (Kerala) }\end{array}$ & $\begin{array}{l}\text { NPOP } \\
\text { USDA } \\
\text { NOP }\end{array}$ & \\
\hline 6 & $\begin{array}{l}\text { Natural Organic Certification } \\
\text { Agency (NOCA), Pune }\end{array}$ & $\begin{array}{l}\text { NPOP } \\
\text { USDA } \\
\text { NOP }\end{array}$ & \\
\hline 7 & 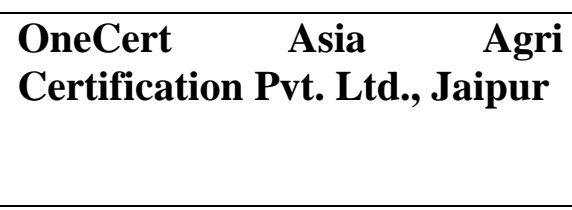 & $\begin{array}{l}\text { NPOP } \\
\text { USDA } \\
\text { NOP }\end{array}$ & \\
\hline 8 & $\begin{array}{l}\text { SGS India Pvt. Ltd. } \\
\text { Gurgaon-Hryana }\end{array}$ & $\begin{array}{l}\text { NPOP } \\
\text { USDA } \\
\text { NOP }\end{array}$ & \\
\hline 9 & $\begin{array}{l}\text { Control Union Certifications, } \\
\text { Mumbai }\end{array}$ & $\begin{array}{l}\text { NPOP } \\
\text { USDA } \\
\text { NOP }\end{array}$ & \\
\hline
\end{tabular}




\begin{tabular}{|c|c|c|c|c|}
\hline \begin{tabular}{|l|}
10 \\
\end{tabular} & $\begin{array}{l}\text { Uttarakhand State Organic } \\
\text { Certification Agency } \\
\text { (USOCA) }\end{array}$ & $\begin{array}{l}\text { NPOP } \\
\text { USDA } \\
\text { NOP }\end{array}$ & & II \\
\hline \begin{tabular}{|l|}
11 \\
\end{tabular} & $\begin{array}{l}\text { APOF Organic Certification } \\
\text { Agency } \\
\text { (AOCA) } \\
\text { Bangalaore }\end{array}$ & NPOP & & $\infty$ \\
\hline \begin{tabular}{|l}
12 \\
\end{tabular} & \begin{tabular}{|ll} 
Rajasthan & Organic \\
Certification Agency (ROCA)
\end{tabular} & NPOP & & \\
\hline \begin{tabular}{|l}
13 \\
\end{tabular} & $\begin{array}{l}\text { Vedic Organic Certification } \\
\text { Agency } \\
\text { Hyderabad }\end{array}$ & $\begin{array}{l}\text { NPOP } \\
\text { NOP } \\
\text { (w.e.f } \\
\text { 2011) }\end{array}$ & 01-10- & Vedie Opgan \\
\hline 14 & $\begin{array}{l}\text { ISCOP (Indian Society for } \\
\text { Certification of Organic } \\
\text { Products) } \\
\text { Coimbatore-Tamil Nadu }\end{array}$ & NPOP & & \\
\hline 15 & $\begin{array}{l}\text { Food Cert India } \\
\text { Pvt. Ltd } \\
\text { Hyderabad }\end{array}$ & $\begin{array}{l}\text { NPOP } \\
\text { NOP } \\
\text { (w.e.f } \\
2011)\end{array}$ & $1-6-$ & Tind \\
\hline \begin{tabular}{|l}
16 \\
\end{tabular} & $\begin{array}{l}\text { Aditi Organic Certifications } \\
\text { Pvt. Ltd } \\
\text { Bangalore }\end{array}$ & $\begin{array}{l}\text { NPOP } \\
\text { NOP } \\
\text { (w.e.f } \\
\text { 2010) }\end{array}$ & 1-6- & \\
\hline \begin{tabular}{|l|}
17 \\
\end{tabular} & 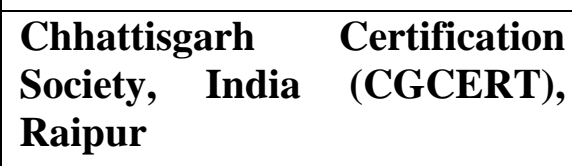 & NPOP & & \\
\hline \begin{tabular}{|l}
18 \\
\end{tabular} & $\begin{array}{l}\text { Tamil Nadu Organic } \\
\text { Certification Department } \\
\text { (TNOCD), Coimbatore }\end{array}$ & NPOP & & \\
\hline \begin{tabular}{|l}
19 \\
\end{tabular} & $\begin{array}{l}\text { Intertek India Pvt. Ltd. } \\
\text { New Delhi }\end{array}$ & $\begin{array}{l}\text { NPOP } \\
\text { NOP } \\
\text { (w.e.f } \\
\text { 2011) }\end{array}$ & 01-10- & K \\
\hline 20 & $\begin{array}{l}\text { TUV India Pvt. Ltd. } \\
\text { Mumbai }\end{array}$ & NPOP & & Member of $7 U N$ NORD Group \\
\hline
\end{tabular}


Table.1 Total area and number of farmers under organic certification process (2009-10)

\begin{tabular}{|l|l|l|}
\hline States & Total area (ha) & Total no. of farmers \\
\hline Madhya Pradesh & 378572.26 & 151953 \\
\hline Maharashtra & 105172.62 & 44551 \\
\hline Orissa & 79086.99 & 49523 \\
\hline Gujarat & 53596.95 & 19353 \\
\hline Himachal Pradesh & 437.09 & 346 \\
\hline J \& K & 430.63 & 132 \\
\hline Delhi & 77.3 & 4 \\
\hline Bihar \& Jharkhand & 0 & 0 \\
\hline
\end{tabular}

Source: National project on organic farming, Department of Agriculture and Cooperation, Government of India.

\section{Inspection and Certification rates}

\begin{tabular}{|l|l|l|}
\hline Category & Details & Fees (Rs) \\
\hline Small farmers and co- operatives & Travel and inspection & $12000 /$ day \\
& Report preparation & 5000 flat fee \\
& Certification & $5000 /$ certificate \\
\hline Estate manufacturers and processors & Travel and inspection & $19200 /$ day \\
& Report preparation & 5000 flat fee \\
& Certification & $5000 /$ certificate \\
\hline Large and medium sized processors & Travel and inspection & $16800 /$ day \\
& Report preparation & 5000 flat fee \\
& Certification & $5000 /$ certificate \\
\hline
\end{tabular}

Source: Org-Marg, 2002

\section{Frame Conditions of Organic Farming for the Various Categories}

\begin{tabular}{|l|l|l|}
\hline Category & Present problems & What needs to be changed? \\
\hline $\begin{array}{l}\text { Government } \\
\text { authorities }\end{array}$ & $\begin{array}{l}\text { So far low involvement/ interest } \\
\text { Lots of paper work (e.g. duty) } \\
\text { No initiatives to educate farmers } \\
\text { Delay in policy implementation } \\
\text { Target only export market } \\
\text { No marketing support }\end{array}$ & $\begin{array}{l}\text { Provide subsidies to organic producers } \\
\text { Reduce documentation } \\
\text { Education and training } \\
\text { Creating awareness among Indian consumers (market } \\
\text { promotion) }\end{array}$ \\
\hline $\begin{array}{l}\text { Certification } \\
\text { organizations }\end{array}$ & $\begin{array}{l}\text { High cost of certification } \\
\text { No standardization in terms of regulations }\end{array}$ & $\begin{array}{l}\text { Reduce cost of certification } \\
\text { Link up with NGO's } \\
\text { Standardize regulations }\end{array}$ \\
\hline NGO's & $\begin{array}{l}\text { Lack of funds } \\
\text { Not completely linked with cert. agencies } \\
\text { Lack of proper infrastructure } \\
\text { Unorganized }\end{array}$ & $\begin{array}{l}\text { Availability of funds } \\
\text { Improved infrastructure } \\
\text { Organized operations }\end{array}$ \\
\hline Traders- domestic & $\begin{array}{l}\text { Low level of awareness } \\
\text { Low domestic markets } \\
\text { Low price realization } \\
\text { Lack of proper marketing network }\end{array}$ & $\begin{array}{l}\text { Create awareness (promotion) } \\
\text { Increase retail chain of organic products } \\
\text { Support for marketing initiatives }\end{array}$ \\
\hline Process industries & $\begin{array}{l}\text { Lack organic raw materials } \\
\text { No standardization in terms of processes } \\
\text { No dependable supply of organic products } \\
\text { Non availability of upgraded processing technologies }\end{array}$ & $\begin{array}{l}\text { Improve availability of organic raw materials } \\
\text { Process standardization } \\
\text { Improve market information } \\
\text { Availability of latest technologies }\end{array}$ \\
\hline $\begin{array}{l}\text { Not organized } \\
\text { Some do not provide benefits to associated farmers } \\
\text { Over expectations } \\
\text { Lack of organic raw materials } \\
\text { Lack of effort to target domestic market } \\
\text { Lack of modern technologies }\end{array}$ & $\begin{array}{l}\text { Organized network } \\
\text { Organizations should provide proper margins to farmers } \\
\text { Realistic information } \\
\text { Organize supply } \\
\text { Support through modern technology }\end{array}$ \\
\hline
\end{tabular}


Cost estimate comprising of certification charge, inspection charge, travel cost, reporting cost, laboratory charges etc. is sent for acceptance

Acceptance of cost by the grower/producer

Signing of agreement between the grower/producer and the cert. agency

Cert. agency raises an invoice and asks the producer to release $50 \%$ of the certification cost in advance

Grower/producer pays the fee

Inspection schedule is worked out

Inspection is carried out at one or more occasion

If required unannounced inspection can also be done. In case of doubt, the inspection team can also draw plant/soil/raw material/input/product sample for laboratory analysis

Inspection report is submitted to the cert. committee

Cert. agency asks for final payment

Final payment is made

Certification is granted

Grower/producer releases the stock for sale with certification mark (India Organic Logo).

\section{Converting a farm as organic}

Initially, a farm is inspected and a report is lodged with the certification review committee (CRC). If CRC recommends, the farm enters the certification system, it will be placed "Under Supervision" for the first 12 months. During this time, produce or products cannot be sold as 'Certified Organic" or as 'in conversion to Organic".
After 12 months, the farm may be upgraded to "In Conversion" if the second inspection is satisfactory. The farm must then complete two years "In Conversion" before it is considered for certifying as "Organic"(otherwise known as "A GRADE Organic")

The "In conversion" period may be reduced - but only where it can be demonstrated that a farm had, during the years immediately preceding conversion, used techniques closely allied to those of organic agriculture and which meet all testing and inspection requirements. Whatever the length of the conversion period, product may not be sold as "In conversion to Organic" until a farm has been under an inspection system for 12 months. Once satisfied, the committee will then recognize the farm as organic.

In the case of other farm activities not being certified, those activities must be clearly separated and the products must be of a different nature from the certified produces or products. There cannot be organic and non -organic growing (parallel production) of the same species on the same property-or on any other property under the same grower's management or control.

When a defined area is certified, the remainder of the farm must be converted to organic within 10 years.

\section{Inspection and certification rates}

Most certifiers are charging inspection and certification fees based on the number of persondays involved, plus fees for the issue of certificates. Sometimes, different fees are applied for small farmers, large farmers, and processors or traders. An example of the fee structure of a certification body operating in India is given below:

\section{Certification issues}

Organic certification is not without its critics. Some of the staunchest opponents of chemicalbased farming and factory farming practices also oppose formal certification. They see it as a way 
to drive independent organic farmers out of business, and to undermine the quality of organic food.

\section{Obstacle to small independents}

Originally, in the 1960s through the 1980s, the organic food industry was composed of mainly small, independent farmers, selling locally. Organic "certification" was a matter of trust, based on a direct relationship between farmer and consumer. Critics (Meirelles, 2011) view regulatory certification as a potential barrier to entry for small producers, by burdening them with increased costs, paperwork, and bureaucracy.

\section{Manipulation of regulations}

Critics of formal certification also fear an erosion of organic standards. Provided with a legal framework within which to operate, lobbyists can push for amendments and exceptions favorable to large-scale production, resulting in "legally organic" products produced in ways similar to current conventional food. Combined with the fact that organic products are now sold predominantly through high volume distribution channels such as supermarkets, the concern is that the market is evolving to favor the biggest producers, and this could result in the small organic farmer being squeezed out.

\section{Recommendations}

In India organic production has yet to be developed. In order to understand the frame conditions of organic farming for the various categories viz. Government authorities, certification organizations, NGOs, traders, processing industry and producers, various problems and suggestions were discussed and are summarized below:

\section{References}

APEDA. 2006. Accredited inspection and certification bodies. In National program for organic agriculture (NPOP) standards.

Cornish, P.S. and Stewart, T.E.B. 2002. Certification - case studies with Australian market gardeners. In: Thompson, R. (ed.) Cultivating Communities. Proceedings of the 14th IFOAM Organic World Congress, 21-28 August 2002, Victoria, Canada. Canadian Organic Growers, Ottawa. p. 222.

Kirchmann, H. and Ryan, M.H. 2004. Nutrients in organic farming - are there advantages from the exclusive use of organic manures and untreated minerals. In: Fischer, T., Turner, N., Angus, J., McIntyre, L., Robertson, M., Borrell, A. and Lloyd, D. (eds). New directions for a diverse planet. Proceedings of the $4^{\text {th }}$ International Crop Science Congress. 26Sept.-1 Oct. 2004, Brisbane, Australia. The Regional Institute, Gosford. pp. CD ROM.

Meirelles, Laércio. 2011. Certification of Organic Products. Central Ecologico. http://www.centroecologico.org.br/artigo_ detalhe.php?id_artigo $=26$

Trewavas, A. 2001. Urban myths of organic farming. Nature. 410: 409-410.

Trewavas, A. 2004. A critical assessment of organic farming-and-food assertions with particular respect to the UK and the potential environmental benefits of no-till agriculture. Crop Protection. 23(9): 757781.

\section{How to cite this article:}

Ummyiah, H.M., N. Jabeen, Baseerat Afroza, Faheema Mushtaq, Shahnaz Mufti and Ambreen Nabi. 2017. Certification of Organic Products. Int.J.Curr.Microbiol.App.Sci. 6(11): 2300-2308. doi: https://doi.org/10.20546/ijcmas.2017.611.273 